\title{
Tax Culture - the Basis of Russian Tax System
}

\author{
Timergaziz Gabidullovich Sadykov \\ Department of Humanities and Socio-Economic Sciences \\ Ufa State Petroleum Technological University, Branch of the University in the City of Oktyabrsky \\ Oktyabrsky, Republic of Bashkortostan, Russian Federation \\ E-mail: riuof@mail.ru
}

\begin{abstract}
- the paper considers the development of tax culture as one of the main directions of tax system reforms. Special attention is paid to the problems of tax compliance, conduct, and literacy of the population. In the present-day conditions of economic development, the tax culture education of the population requires increasingly new modern approaches. The development of tax culture is a complex process with economic, social, informational, and legal aspects. It acts as a regulator of conduct, compliance, and literacy not only for every taxpayer, but also for the tax officer. Thus, tax culture represents a set of subjective and objective factors and forms of the taxpayer's relations with tax service bodies, which contributes to the harmonious development of the Russian tax system.
\end{abstract}

Keywords - tax system, tax culture, tax compliance, tax behavior, tax literacy, tax legislation.

\section{INTRODUCTION}

Taxes as the main source of public finances are known since time immemorial. It is known that the level of tax relations contributes to the growth of tax revenues, which in turn is the main item of income of the state budget.

That is why the improvement of tax relations is among the key problems to be solved for the development of the country's economy.

In recent years, the society has been facing the need to renew the state strategy for the development of tax culture ever more urgently.

The world experience of the country's governance aims at the need for a scientifically sound approach to a new national tax culture taking into account economic, financial, demographic, and social characteristics of the state [1].

\section{MATERIALS AND METHODS}

Tax culture is a subsystem of economic culture and represents the relations between a taxpayer and the state.

In modern Russia, due to difficult socio-economic conditions, the role and importance of tax culture are rapidly growing. More than a third of the population lives below the poverty line, and many organizations and enterprises cannot adapt to the conditions of a market economy fighting high taxation. Therefore, those who avoid taxes are admired and draw praise from the others.

Therefore, the level of tax culture of the population in the country remains quite low. This problem is not exclusively specific for Russia, as evidenced by the data of sociological survey carried out in foreign countries. The distinguishing feature of Russian taxpayers is the emerging distrust of the population for state institutions involved in taxation [3].

Noting the low level of tax culture of the population in Russia it is necessary to note the following:

- financial illiteracy;

- low awareness on tax authorities and taxpayers;

- habit of a Soviet person of free public goods;

- lack of tax system and taxation, etc.

The main problem in the tax culture of the Russian Federation is also the insufficient level of state participation in this process. Despite the measures taken to manage taxation, to tighten tax administration, the tax culture in the country is still far from being ideal.

The population still does not perceive the fundamental generally accepted political values of taxation in the society as "the basis for the well-being of the state and the society.

Another factor explaining the low level of tax culture in our country, unlike the developed countries of the West, is that in these countries the practice of taxation has much longer history, and the improvement of it went exclusively evolutionary, as opposed to the revolutionary path of development of the Russian taxation practice [2].

It should be noted that tax default in Russia almost does not affect the image, business reputation of an enterprise and citizens. The increased tax pressure fosters tax collection crisis thus creating a vicious cycle of tax avoidance.

Without descending in the history of our state it is necessary to note what the socio-economic level has developed as a result of formation and transformation in the modern state. As is commonly known, in the 1990s Russia experienced economic, social, and political crisis. Against the background of the collapse of the USSR there was a decline in production, poverty of the population, a new class-type composition of the society, as well as sharp income inequality [1].

The redistribution of the national wealth in favor of a small circle of people, the dominance of Western promotion of material values, high tax burden placed sufficiently large number of the population in the conditions of physical survival. The number of different types of taxes reached 300 . As a result, local governments had quite a wide range of powers. They imposed their own taxes on the ground. At the same time, tax rates such as VAT (about 28\%), income tax 
(43\%) was quite high, and the income tax rate simply plunged everyone into horror, as it reached $60 \%$.

All this contributed to the bankruptcy of many enterprises and, therefore, chronic arrears in the budget. At that time there was nothing similar to tax culture.

With the onset of 2000, the economy began to rise slowly from its knees. Many areas, including taxation, were subject to reforms and improvements, which as a result helped to significantly reduce the number of taxes, establish their administration, introduce special regimes and reduce the tax burden of taxpayers [2].

But all these reforms have never been able to stabilize the tax legislation, so even now it continues to change, which in general, does not have a particularly favorable impact on the perception and serious attitude of Russian citizens to taxation.

The difference from the countries of Western Europe is that high tax culture manifests itself in the fact that the payment of taxes is considered a subject of pride of a taxpayer and the tax culture is instilled from childhood, while in Russia there are hostile feelings towards taxes.

It is necessary to teach tax culture from childhood - such conclusion was reached by academic economists and experts that have studied the issues of tax culture development.

Without demonstrating clear examples of fair tax legislation in practice, it is impossible to increase the level of tax culture and the number of bona fide taxpayers. The example of parents who must also learn to take responsibility for their actions plays a very important role in the development of the identity of a child [4].

It can clearly be concluded that it is necessary to instill tax culture to a person during the period of his/her development as a person.

\section{Tax compliance}

Tax compliance is the most important element of tax culture.

Tax compliance is systematic learning, development and control of moral and financial abilities and capabilities of a taxpayer to settle the budget taking into account the interaction with tax authorities on acceptance and registration of taxes and tax liabilities.

The control function of taxes, its completeness and depth to a certain extent depends on tax compliance. At the same time, the task of tax authorities is not to punish taxpayers through tax audits, but to motivate them to voluntarily refuse from tax evasion tools [7].

One of the most important conditions for stabilizing the financial system of any state is to ensure sustainable collection of taxes with proper compliance of taxpayers. Taxpayer compliance is the main element of tax culture and the basis of taxpayer literacy.

Compared to developed foreign countries, the state of Russian tax system is currently characterized by a low collection of taxes and fees. Almost one in three taxpayers violates the law by hiding their income and property, and only about $20 \%$ pay their taxes relatively honestly and properly [5].

The on-site audits held in the Russian Federation in 2017 revealed violations in more than $90.0 \%$ cases out of 17.6 thousand, and 12.3 million rubles were additionally charged per 1 audit.

In 2018, 14.2 thousand audits revealed more than $95.0 \%$ violations; the additional taxes already amounted to 17.2 million rubles per audit.

The level of additional recovery of taxes and fines in 2017 made $60.5 \%$, in $2018-66.4 \%$.

The analysis of enterprises subjected to tax audits, although their number is decreasing, shows that in 2017 their number was $0.37 \%$, in $2018-0.31 \%$. In 2015 this indicator amounted to $0.54 \%$, and the number of audits made 26.2 thousand.

Practice shows that the efficiency of on-site audits remains quite high, on average only 2 out of 100 audits end without additional charges and fines [4].

The requirements of tax compliance apply not only to taxpayers (legal entities and individuals), but also to state authorities of various levels, their officials.

Private changes in tax legislation, as well as the increase in its level, which is a difficult task with a multifaceted number of requirements has a negative influence on the development of tax compliance [6].

The growing importance of improving the tax compliance of the population shall be based on new and modern approaches to taxpayers. The public awareness effort of inspectors and consultants is a top priority.

Using the experience of foreign countries, it is possible to compare the needs and realities of utilizing tax consultants. The advanced countries of Europe and the United States have an average ratio of 11 consultants per 10 tax officers working in the country. In Australia, there are 18,000 tax officers and 21,000 tax advisers per 18 million people. In Russia, 140 thousand people work in tax authorities, about 155 thousand consultants are needed, and only 5 thousand consultants work in reality.

The improvement of tax compliance is only possible with a clearly formed connection between the subjects of tax relations and the state, depends on the social position of all participants of tax relations.

Despite the measures taken within the framework of the tax policy in the field of simplification and tightening of tax administration, tax compliance in the Russian Federation requires close attention and improvement [8].

\section{Tax behavior}

In modern conditions taxation depends on the level of tax behavior of all its participants. The concept of tax behavior is closely related to the concept of tax compliance, which in turn has a direct impact on the formation of tax culture. As a form 
Thus, tax literacy is not only a part, but also a basis for the of economic behavior, tax behavior depends on the paying capacity of taxpayers [7].

Most of the economic studies on tax behavior are mainly focused on two directions [9]:

1. Tax behavior is effectively identified with the decision to evade taxes based on the criterion of maximizing the net income (revenue).

2. Tax behavior extends to various economic actions influenced by taxes.

By the nature of tax payment by enterprises and organizations, the following areas of behavior can be considered [8]:

- law-abiding;

- risky;

- reasonable.

1. Law-abiding behavior includes enterprises that pay taxes under the Russian law and do not seek to reduce them.

In considering this behavior, it is necessary to highlight tax evasion. The analysts estimate that up to $30 \%$ of enterprises and organizations in Russia apply various schemes to minimize payments, especially those related to remuneration.

2. Risky tax behavior - these are enterprises that apply optimization methods by using ways to challenge their actions in court, but do not use the results of judicial practice.

3. Reasonable tax behavior - these include taxpayers performing tax optimization:

- according to the civil legislation in force,

- according to the right to determine the tax regime for business;

- according to the current legislation on taxes and fees, representing the possibilities of choosing different methods of accounting for business transactions at own discretion.

Along with the recovery of the economy and optimization of taxes, there is a need for targeted work on the formation of tax behavior.

In modern Russian society, there is almost no understanding that the payment of taxes helps to solve economic and social problems of every resident [9].

It is important to prepare and implement the state program for the promotion of tax culture and education, the need for which is constantly covered in the press.

\section{Tax literacy}

At the current stage of economic instability and political influence of Western countries, including far-fetched sanctions, the issue of improving the tax literacy of the population as a whole, i.e. the education of competent taxpayers, is critical for the country.

Today, the most discussed problem of the country's economy is tax illiteracy. In turn, low tax literacy raises a number of issues such as:

- development of the shadow economy;

- low level of yield income to the budget;

- social tensions;

- economic destabilization, etc. formation of tax culture, plays an important role in the development of the country's economy thus emphasizing the need for tax knowledge and skills [10].

Public literacy in tax matters is an important task for the modern society. According to experts, at present the main goal of increasing the tax literacy of the population is as follows:

- a clear understanding of the tax system in the Russian Federation;

- ability to find the necessary information about taxation, knowledge on tax risks, favorable tax regimes, privileges, etc.;

- skills to manage personal finances and investment processes.

Practice shows that a large part of the population does not possess computer literacy skills or Internet skills, since the modern system of public services is mainly conducted online.

Many citizens do not know where to obtain reliable information on the current procedure for calculating taxes and fees, on the introduction of new norms of legislative and regulatory legal acts regulating tax relations, on their rights and obligations. As a result, the responsibility for decisions is reduced, such as late and incomplete payment of taxes, tax evasion; facilitating the development of the "shadow market" and "under-the-counter wages"; criminal sector [11].

Tax literacy is the timely payment of taxes to the budget, within the period established by law, knowledge and ability of the population to calculate and check the accrued tax, and the ability to apply tax deductions and incentives [12-15].

The concept of tax literacy includes activities related to the work of qualified specialists who shall interact with taxpayers.

Thus, the experience of different foreign countries shows that it is efficient to study tax bases from school, as well as at universities.

In our country, many universities, such as Plekhanov Russian University of Economics and all its branches hold the weeks of financial literacy, meetings with tax inspectors, where they share different information in order to increase tax literacy.

Various trainings and seminars are held for the population who has already received the corresponding education.

It is simply necessary to know the main provisions of tax legislation in order to adjust the strategic plans, to optimize the resulting tax burden.

Therefore, tax literacy is relevant not only for large companies or individual entrepreneurs, but also for ordinary citizens.

After all, without increasing tax literacy, it is difficult to overcome legal nihilism, which, unfortunately, today is typical for Russians. The current situation demonstrates the need for systemic policies aimed at improving the tax literacy of the population.

It is tax literacy that serves the basis for the formation of the tax culture of citizens. Therefore, the first step towards achieving the economic development of the country should be 
to increase the level of tax literacy of the population. The high level of tax and financial literacy is the basis for the formation of a successful state and the society.

\section{RESULTS}

The state of tax culture in the country depends on the level of its tax system. In turn, the system of taxation is effective only at a high level of development of both the economy and the tax culture in the society.

The development of a tax culture is a complex process with economic, social, informational and legal aspects. It acts as a regulator of conduct, compliance and literacy not only for every taxpayer, but also for the tax officer. Thus, tax culture represents a set of subjective and objective factors and forms of the taxpayer's relations with tax service bodies, which contributes to harmonious development of the Russian tax system.

\section{CONCLUSION}

The paper considers the development of tax culture from three perspectives:

- from the point of view of taxpayers and the state;

- as an educational process;

- as a motivational process of subjects to rational application of tax legislation norms.

The author separately analyzes the components of tax culture:

- tax behavior;

- tax compliance;

- tax literacy.

The possibility of applying the positive experience of foreign countries is emphasized.

The author proposes the need to design a program for tax culture development among taxpayers taking into account that the low level of tax literacy, discipline and conduct causes material damage to the state and the population.

\section{References}

[1] T.V. Zakupen "Some aspects of tax policy" Finance No5.-p.30, 2015

[2] T.G. Sadykov, R.R. Stepanova, "Municipal budgets under conditions of economic crises in Russia". SHS Web of Conf. vol. 50, pp. 1-3 April
2018 (CILDIAH-2018, 2018) DOI: 10.1051/shsconf/ 20185001219economics

[3] Sadykov T.G. "Formation of expenses of the budget" Financial Economics, vol. 4, p. 22, 2009

[4] T.G. Sadykov, "Municipal budgets in the period of financial and economic crisis" Ufa, p. 712018

[5] M V Goryunova, L S Kuleshova, and A I Khakimova, "Application of signal analysis for diagnostics," 2017 International Conference on Industrial Engineering, Applications and Manufacturing pp. 1795-1799, May 2017 (ICIEAM, 2017), DOI: 10.1109/ICIEAM.2017.8076487

[6] N.T. Dao, O. Edenhofer, "On the fiscal strategies of escaping povertyenvironment traps towards sustainable growth" J. of Macroeconomics, vol. 55, 253-273, 2018

[7] M.A. Mateo-Perez, M.A. Martinez-Roman, Y Domenech-Lopez, "Social services in times of economic and social crisis: the case of Spain" Revista de cercetare si interventie sociala, vol. 50, pp. 96-110 2015

[8] E.R. Toro, "Debemos avanzar hacia una transformación de la administración pública local? / Do we move towards the transformation of local public administration?" Revista gestion de las personas y technologia, vol. 9, iss. 25, pp. 6-19, 2016

[9] I.A. Samsonova, E.N. Smolyaninova, V.S. Prosalov, "Tax literacy of the population as a way of protecting the financial interests of citizens. Territory of new opportunities," Bulletin of Vladivostok University of Economics and Service, no. 5 (9), pp. 82-88, 2010.

[10] O.V.Derina, G.V. Morozova "Tax culture in Russia: modern problems and directions of increase" Vector of Economics.2017. No4. Retrieved from: https: //www.vectoreconomy/ru/imaqe/2017/4/taxes/Derina_Morozo

[11] E.D. Leonova "Tax culture as a vad element of improving the tax system of Russia" Taxes and Taxation. 2015. No. 9, Retrieved from: https://cyberleninka.ru/article/n/povyshenie-nalogovoy-gramotnosti-ikultury-uchastnikov-nalogovyh-pravootnosheniy

[12] V.E. Andreev, A.P. Chizhov, Yu.A. Kotenev, Sh.Kh. Sultanov, V.Sh. Mukhametshin, A.V. Chibisov, "Prediction of Gas Exposure in the Conditions of the Oil Fields of the Volga-Urals," Atlantis Highlights in Material Sciences and Technology vol. 1, pp. 666-669, June 2019 (ISEES 2019, p. 775, 2019),. DOI: 10.2991/isees-19.2019.132.

[13] R.T. Akhmetov, V.V. Mukhametshin, and L.S. Kuleshova, "Grouping of objects using a limited number of parameters characterizing geological and physical properties of layers," Atlantis Highlights in Material Sciences and Technology vol. 1, pp. 9-13, June 2019 (ISEES 2019, p. 775, 2019),. DOI: 10.2991/isees-19.2019.3.

[14] L.S. Kuleshova and V.V. Mukhametshin, "Estimation of the wells hydrodynamic drag level based on wells geophysical survey data," Atlantis Highlights in Material Sciences and Technology vol. 1, pp. 727-729, June 2019 (ISEES 2019, p. 775, 2019), DOI: 10.2991/isees19.2019 .145

[15] M.K. Rogachev, V.V. Mukhametshin, and L.S. Kuleshova, "Improving the efficiency of using resource base of liquid hydrocarbons in Jurassic deposits of Western Siberia," Journal of Mining Institute, vol. 240, pp. 711-715, 2019. DOI: 10.31897/PMI.2019.6.711. 